\title{
PEMODELAN RESERVOAR PANASBUMI MENGGUNAKAN METODE GEOMAGNET DI DESA LENGKEKA KECAMATAN LORE BARAT, KABUPATEN POSO
}

\section{MODELLING OF GEOTHERMAL RESERVOIR OF LENGKEKA VILLAGE USING METHOD OF GEOMAGNET IN WEST LORE DISTRICT, REGENCY OF POSO}

\author{
Andi Moh. Asrul, RustanEfendi, Sandra \\ Jurusan Fisika Fakultas Matematika dan Ilmu Pengetahuan Alam Universitas Tadulako
}

\begin{abstract}
This research was conducted using geomagnet method on geothermal area in village lore Barat of Poso regency. This study aims to determine the geothermal reservoir in the study sites. The data was then processed by doing correction of IGRF and daily was variations to obtain the total earth magnetic field data. subsequent modeling is done to find the geothermal reservoir rock composer and its depth forward modeling technique with GM-SYS software. From the result of modeling, it was found that the reservoir rock are sedimentary rock in the form of sandstone with susceptibilty of -0,00001 SI at A-A 'section, -0.00713 SI at B-B' section and -0.0011 SI at C-C ' section on each track. The depth of the geothermal reservoir is $1,000-2,000 \mathrm{~m}$ below the surface.
\end{abstract}

Keywords : Forward modeling, Reservoir, susceptibilty

\begin{abstract}
ABSTRAK
Penelitian ini telah dilakukan menggunakan metode geomagnet pada daerah panas bumi Kecamatan Lore Barat Kabupaten Poso. Penelitian ini bertujuan untuk menentukan reservoar panasbumi di lokasi penelitian. Data yang didapatkan selanjutnya diolah dengan melakukan beberapa koreksi yaitu koreksi IGRF dan koreksi variasi harian guna memperolah data medan magnet total bumi. selanjutnya dilakukan pemodelan untuk mengetahui batuan penyusun reservoar panasbumi dan kedalamnnya menggunakan teknik pemodelan kedepandengan software GM-SYS. Dari hasil pemodelan diperoleh bahwa batuan penyusun reservoar yaitu batuan sedimen berupa batu pasir dengan nilai suseptibilitas $-0,00001$ SI pada penampang A-A', -0,00713 SI pada Penampang B-B' dan -0,0011 SI pada Penampang C-C' pada setiap lintasan. Kedalaman reservoar panasbumi berada 1.000-2.000 m di bawah permukaan.
\end{abstract}

Kata kunci: Pemodelan Kedepan, Reservoar, Suseptibilitas 


\section{LATAR BELAKANG}

Energi panasbumi adalah energi panas yang tersimpan dalam batuan di bawah permukaan dan fluida yang terkandung di dalamnya. Energi panasbumi dapat digunakan sebagai pengganti tenaga listrik yang menggunakan bahan bakar minyak sehingga dapat dijadikan sumber energi alternatif untuk menghemat cadangan minyak nasional. Panasbumi merupakan salah satu sumber daya alam yang memiliki potensi sangat besar untuk dimanfaatkan. Banyak manifestasi panasbumi yang terdapat di Provinsi Sulawesi Tengah salah satunya ada di Kabupaten Poso.

Kecamatan Lore Barat Kabupaten Poso Provinsi Sulawesi Tengah memiliki manifestasi panasbumi, berupa air panas. Salah satu contoh adalah yang berada di Desa Lengkeka. Pemanfaatan panasbumi sebagai energi alternatif memerlukan banyak pertimbangan khususnya yang berkaitan dengan struktur bawah permukaan. Keberadaan sumber air panas tersebut mendorong untuk dilakukan penelitian guna mengetahui fenomena panas bumi di daerah tersebut. Salah satu metode yang dapat digunakan untuk mengetahui keberadaan sumber air panas (reservoar) panasbumi adalah metodegeomagnet.

Metode geomagnet telah banyak digunakan oleh peneliti sebelumnya misalnya oleh Afandi (2013), yang dapat mengidentifikasi reservoar daerah panasbumi menggunakan metode geomagnet di daerah Blawan Kecamatan Sempol Kabupaten Bondowoso dengan nilai rata-rata Reservoar $-0,178$ SI sampai -0,199 SI dan kedalamanya mencapai $500 \mathrm{~m}$ - $2000 \mathrm{~m}$, Fitria (2015), dapat mengidentifikasi struktur bawah permukaan berdasarkan data geomagnetik pada daerah mata air panas Jatikurung Kabupaten Semarang denagan nilai suseptibilitas yang di duga sebagai lapisan reservoar yaitu 0,0057SI dengan kedalam $326 \mathrm{~m}$ hingga $1200 \mathrm{~m}$, Indriatmoko (2009), menginterpretasi bawah permukaan daerah manifestasi panasbumi Parang Tritis Kabupaten Bantul DIY dengan metode magnetik dengan nilai Suseptibilitas reservoar yang didapat yaitu $-0,0085$ SI dan kedalamanya mencapai $580 \mathrm{~m}$, Baligau (2017), pemodelan panasbumi menggunakan data magnetik di Desa Toro Kecamatan Kulawi dengan nilai suseptibilitas reservoar $-0,003413$ SI sampai -0,00446 SI dengan kedalaman >2000 m dan Putri (2017), Pemodelan Reservoar panasbumi menggunakan data magnetik di Desa Bora Kabupaten Sigi dengan nilai suseptibilitas 0,000002 SI sampai 0,000012 SI dengan kedalaman $>2000$ M. Dalam penelitian ini metode geomagnet diaplikasikan untuk memperoleh data intensitas medan magnet total, memodelkan batuan penyusun sistem dari reservoar panasbumi Desa Lengkeka, menggunakan teknik forward modelling untuk menentukan reservoar panasbumi menggunakan metode geomagnet di Desa Lengkeka.

Saptadjil (2009) berdasarkan pada besarnya temperatur, mengelompokkan sistem panasbumi menjadi 3, yaitu:

1. Sistem/reservoar bertemperatur tinggi, yaitu suatu sistem yang reservoarnya mengandung fluida bertemperatur di atas $225^{\circ} \mathrm{C}$.

2. Sistem/reservoar bertemperatur sedang, yaitu suatu sistem yang reservoarnya mengandung fluida bertemperatur antara $125{ }^{\circ} \mathrm{C}$ dan $225^{\circ} \mathrm{C}$. 
3. Sistem panasbumi bertemperatur rendah, yaitu suatu sistem yang reservoarnya mengandung fluida dengan temperatur lebih kecil dari $125^{\circ} \mathrm{C}$.

Tingkat suatu benda magnetik untuk mampu dimagnetisasi ditentukan oleh Suseptibilitas Kemagnetan atau $k$, yang dituliskan sebagai:

$I=k H$

Jenis batuan sedimen beserta nilai suseptibilitasnya dapat dilihat dalam Tabel 1.

Tabel 1. Nilai suseptibilitas batuan sedimen.

\begin{tabular}{|l|c|c|c|}
\hline \multirow{2}{*}{$\begin{array}{l}\text { Batuan/ } \\
\text { Mineral }\end{array}$} & $\begin{array}{c}\text { Rapat } \\
\text { Massa } \\
\left(10^{3} \mathrm{Kg} \mathrm{m}^{3}\right)\end{array}$ & $\begin{array}{c}\text { Solume }(\mathrm{k}) \\
\left(10^{-6} \mathrm{SI}\right)\end{array}$ & $\begin{array}{c}\text { Massa }(\chi) \\
\left(10^{-8} \mathrm{~m}^{3} \mathrm{~kg}^{-1}\right.\end{array}$ \\
\cline { 3 - 4 } Batuan & & & \\
Sedimen & & $0-18,000$ & 8 \\
Aluvium & 1,65 & $170-250$ & $10-15$ \\
Lempung & 1,70 & 25 & 1,9 \\
Batu Bara & 1,35 & $2-25,000$ & $0,1-1,200$ \\
Gamping & 2,11 & $0-20,900$ & $0-931$ \\
Batupasir & 2,24 & $0-50,000$ & $0,2,000$ \\
Batuan & 2,19 & & \\
Sedimen & & & \\
(Rata-rata) & & & \\
\hline
\end{tabular}

(Telford, 1996)

Dan Beberapa jenis material jika dihubungkan dengan suseptibilitas magnetiknya dapat dilihat dalam Tabel 2 .

Tabel 2. Hubungan antara sifat magnetik dan suseptibilitas magnetik.

\begin{tabular}{|l|l|}
\hline Sifat Magnetik & \multicolumn{1}{|c|}{ Suseptibilitas Magnetik } \\
\hline Ferromagnetik & $\begin{array}{l}\text { Suseptibilitas magnetik tinggi } \\
\text { dan berharga positif Contoh: } \\
\text { Besi (Fe), Nikel (Ni), Khrom } \\
(\mathrm{Cr}) . \\
\text { Suseptibilitas magnetik tinggi } \\
\text { dan berharga positif Contoh: } \\
\text { magnetite }\left(\mathrm{Fe}_{3} \mathrm{O}_{4}\right), \text { pyrotite, } \\
\text { (FeS),ferrite }\left(\mathrm{NiOFe}_{2} \mathrm{O}_{3}\right) . \\
\text { Suseptibilitas sedang dan }\end{array}$ \\
\hline
\end{tabular}

berharga positif Contoh $\mathrm{Fe}_{2} \mathrm{O}_{3}$ (hematite, geothite).

Parramagnetik Suseptibilitas rendah dan berharga positif Contoh : (biotite, olivine).

Diamagnetik Suseptibilitas rendah dan berharga negatif Contoh : air, Material organik.

(Rosanti, 2012)

Metode geomagnet merupakan salah satu metode geofisika (2antg sering digunakan untuk survei pendahuluan pada eksplorasi minyak bumi, panasbumi, batuan mineral, maupun untuk keperluan pemantauan (monitoring) gunung api. Metode ini mempunyai akurasi pengukuran yang relatif tinggi, instrumentasi dan pengoperasian di lapangan relatif sederhana, mudah dan cepat dibandingkan dengan metode geofisika lainnya. Koreksi pembacaan praktis tidak perlu dilakukan (Telford, 1996).

Metode geomagnet sangat sensitif terhadap perubahan vertikal, umumnya digunakan untuk mempelajari tubuh intrusi, batuan dasar, urat hydrothermal yang kaya akan mineral ferromagnetik dan struktur geologi. Metode geomagnet ini digunakan pada studi geothermal karena mineralmineral ferromagnetik akan kehilangan sifat kemagnetannya bila dipanasi mendekati temperatur Curie. Oleh karena itu digunakan untuk mempelajari daerah yang diduga mempunyai potensi geothermal. Metode eksplorasi geomagnet banyak digunakan karena pengambilan dan pengolahan data dilakukan tidak serumit metode gaya berat. Penggunaan filter matematis umum dilakukan untuk memisahkan anomali berdasarkan panjang gelombang maupun kedalaman sumber anomali magnetik yang ingin diselidiki (Broto dan Putranto, 2011).

Medan magnet bumi terkarakterisasi oleh parameter fisis yang dapat diukur yaitu arah 3 
dan intensitas kemagnetannya. Parameter fisis itu adalah deklinasi magnetik $D$, intensitas horizontal $H$ dan intensitas vertikal $Z$. Parameter yang menggambarkan arah medan magnetik adalah deklinasi $D$ (sudut antara utara magnetik dan utara geografis) dan inklinasi $I$ (sudut antara bidang horizontal dan vektor medan total). Parameter ini diukur dalam satuan derajat. Intensitas medan magnetik total $F$ digambarkan dengan komponen horizontal ke arah utara $X$ dan ke arah timur $Y$. Nilai intensitas medan magnetik bumi berkisarantara $25.000 \mathrm{nT}-\quad 65.000 \mathrm{nT}$. Wilayah yang terletak di utara ekuator misalnya Indonesia mempunyai intensitas \pm $40.000 \mathrm{nT}$, sedangkan yang di selatan ekuator $\pm 45.000 \mathrm{nT}$ (Telford, 1996).

Adanya anomali magnetik menyebabkan perubahan dalam medan magnet total bumi dan dapat dituliskan sebagai:

$$
H_{T}=H_{o b s}+H_{M}+H_{L}
$$

Bila besar $H_{o b s}<<H_{L}$ dan arah $H_{o b s}$ hampir sama dengan arah $H_{L}$ maka anomali magnetik totalnya adalah:

$H T=H o b s-H M-H L$

\section{METODE PENELITIAN}

Penelitian ini dilakukan di sekitar daerah Panasbumi Desa Lengkeka, Kecamatan Lore Barat, Kabupaten Poso Provinsi Sulawesi Tengah dapat dilihat pada Gambar 1 peta Geologi lokasi penelitian dan Gambar 2 peta lokasi penelitian.

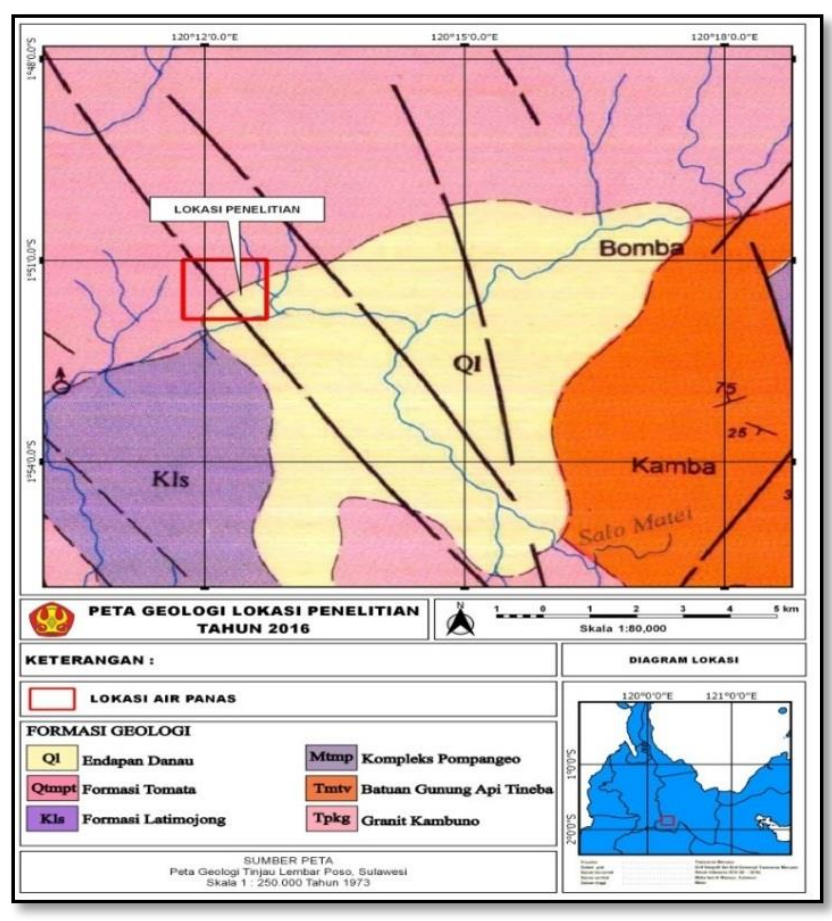

Gambar 1. Peta Geologi Lokasi Penelitian dengan tempat pengambilan data ditunjukan pada kotak merah.

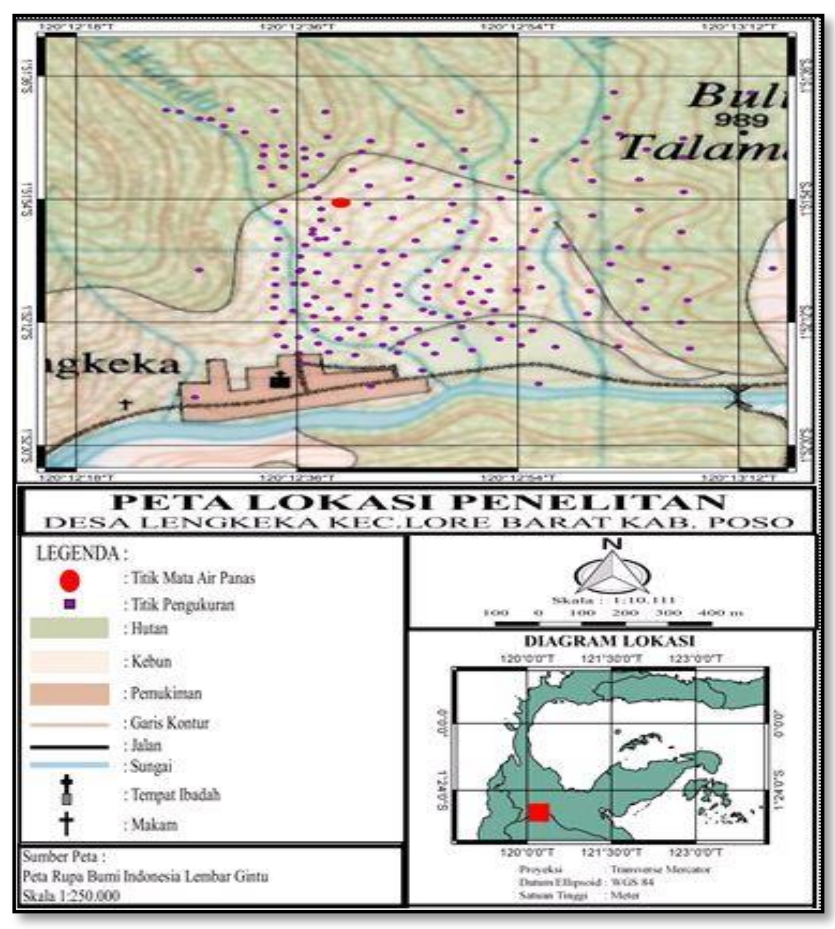

Gambar 2. Peta Lokasi Penelitian dan sebaran titik pengambilan data. 
Secara geografis lokasi penelitian terletak pada posisi $120^{\circ} 12^{\prime} 37,2^{\prime \prime}$ BT dan $01^{\circ} 51^{\prime} 59.1^{\prime}$ ' LS. Penelitian ini dilakukan dengan menggunakan beberapa alat dan bahan penelitian yakni dua set alat Proton Precision Magnetometer merk GS 19T, satu buah kompas geologi, satu buah global positioning system (GPS), Jam, peta geologi dan peta rupa bumi. Pengukuran dalam penelitian ini dilakukan dengan menggunakan 2 alat penelitian yakni alat yang ditempatkan pada base dan alat yang akan mengukur dilapangan. Pengukuran di base dilakukan dengan mengarahkan sensor ke arah utara dengan panduan kompas. Kemudian mengatur dan menyamakan waktu yang akan digunakan pada base dan waktu pada saat pengukuran. Selanjutnya mengatur interval waktu pengukuran otomatis magnetometer yang berada di base sesuai kebutuhan. Adapun interval waktu yang diambil pada penelitian ini setiap 10 menit, kemudian Mencatat perekaman instrumen GSM19T yang ada di base yaitu berupa nilai intensitas medan magnet dan waktu dengan interval setiap 10 menit dengan syarat lokasi. Penempatan alat GS 19T di base harus jauh dari material yang mengandung logam karena akan mempengaruhi keakuratan hasil pengukuran.

\section{HASIL DAN PEMBAHASAN}

Hasil Pengukuran intensitas medan magnet bukan hanya dipengaruhi oleh medan magnet harian, tetapi juga dipengaruhi oleh medan magnet utama bumi yang dapat berubah tiap waktu dan setiap wilayah. Data input yang digunakan untuk memproleh data IGRF adalah data lokasi penelitian (lintang dan bujur) dan elevasi atau ketinggian lokasi penelitian. Nilai IGRF yang diperoleh adalah
41.637,6 nT. digunakan untuk mengkoreksi data intensitas medan magnet sehingga dapat diperoleh nilai medan magnet total.

Berdasarkan data medan magnet yang terukur $\left(T_{o b s}\right)$ di lapangan, selanjutnya dilakukan perhitungan anomali medan magnet total $\left(\Delta T_{\text {total }}\right)$. Setelah mendapatkan nilai anomali medan magnet total kemudian dibuatkan peta kontur anomali medan magnet dengan menggunakan software surfer 11. Untuk membuat peta kontur, data yang digunakan terdiri dari 3 variabel yaitu, lintang dan bujur sebagai sumbu $\mathrm{X}$ dan $\mathrm{Y}$, serta nilai anomali medan magnet total sebagai sumbu $\mathrm{Z}$ yang terlihat pada Gambar 3.

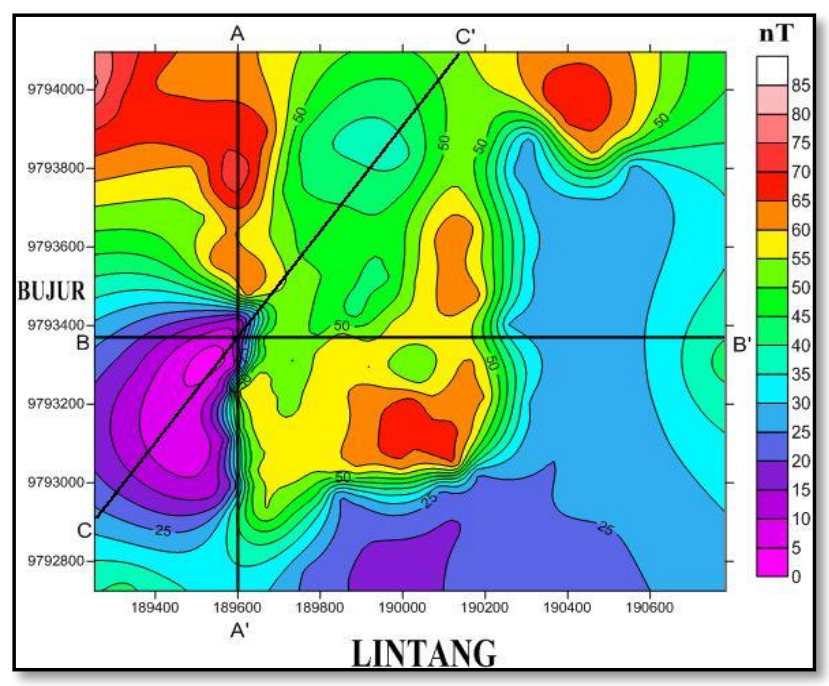

Gambar 3. Peta Kontur anomali medan magnet total $\left(\Delta H_{T}\right)$.

Gambar 3 menunjukan kontur anomali magnetik total dengan nilai intensitas magnet antara $0-85 \mathrm{nT}$. Nilai anomali magnetik tinggi ditunjukan oleh parameter warna putih dan nilai anomali medan magnet rendah ditandai dengan parameter warna ungu muda. Anomali bernilai tinggi terdapat benda magnetik yang memiliki nilai kerentanan magnet besar begitupun sebaliknya. Nilai anomali magnetik yang menunjukan nilai 
rendah diduga diakibatkan oleh benda anomali di bawah permukaan yang memiliki nilai kerentanan magnetik kecil. Nilai magnetik rendah diduga lapisan batuan penyusun reservoar. Pada proses ini, pengamatan difokuskan pada anomali rendah ditunjukan parameter warna ungu muda yang selanjutnya menentukan garis penampang di lokasi pengamatan. Dalam hal ini garis penampang dibuat 3 garis yang saling berpotongan sehingga memudahkan dalam melakukan interpretasi yaitu penampang AA', B-B' dan C-C'.

Untuk mengetahui kondisi bawah permukaan atau batuan penyusun reservoar panasbumi diperlukan teknik pemodelan menggunakan pemodelan kedepan. Pemodelan kedepan, dilakukan dengan cara membangun model lapisan bawah permukaan menggunakan data anomali magnetik total di sepanjang lintasan titik koordinat tertentu pada lokasi penelitian. Penentuan irisan pada lokasi penelitian yang hendak dibangun model bawah permukaannya, berdasarkan pada nilai anomali medan total yang rendah karena dapat diduga bahwa suatu wilayah yang mempunyai nilai anomali medan total yang rendah memiliki nilai suseptibilitas yang rendah juga. Nilai suseptibilitas yang sangat rendah atau bernilai negatif, merupakan batuan yang mengalami kehilangan mineral magnetiknya sebagai akibat dari pemanasan dan tekanan dari sumber panas yang ada di bawah permukaan.

Dalam membangun model menggunakan metode pemodelan kedepan, nilai suseptibilitas batuan dipilih berdasarkan keadaan geologi yang sebenarnya pada lokasi penelitian kemudian dimasukan kedalam perhitungan hingga diperoleh grafik respon intensitas magnetik. Grafik respon pada lokasi tersebut dicocokan dengan grafik model bawah permukaan yang terbentuk dari anomali medan magnet total yang telah diperoleh sebelumnya hingga kesalahan yang didapatkan menjadi kecil yaitu $<5 \%$. Berikut penentuan irisan berdasarkan nilai anomali medan total yang terdiri dari penampang $\mathrm{A}$ A', penampang B-B' dan penampang C-C' ditunjukan pada Gambar 6 .

Tabel 3. Interpretasi jenis batuan/mineral terhadap nilai suseptibilitas benda pemodelan penampang (A-A'), penampang (B-B') dan penampang (C-C').

\begin{tabular}{|c|c|c|c|c|}
\hline \multirow{2}{*}{ Lapisan } & \multicolumn{2}{|c|}{ Nilai Suseptibilitas (SI) } & \multirow{2}{*}{$\begin{array}{c}\text { Interpretasi } \\
\text { Mineral/batuan }\end{array}$} & \multirow{2}{*}{ Keterangan } \\
\hline & Benda & Literatur & & \\
\hline \multicolumn{5}{|c|}{ Penampang A-A' } \\
\hline 1 & 0.000432 & $0-0.018$ & Aluvium & $\begin{array}{c}\text { Batuan } \\
\text { sedimen }\end{array}$ \\
\hline 2 & 0.002382 & $\begin{array}{c}0.00017- \\
0.00025\end{array}$ & Lempung & $\begin{array}{l}\text { Batuan } \\
\text { sedimen }\end{array}$ \\
\hline 3 & -0.00001 & $0-0.02$ & Batu Pasir & $\begin{array}{c}\text { Batuan } \\
\text { sedimen }\end{array}$ \\
\hline 4 & -0.0125 & - & $\begin{array}{l}\text { Mineral non } \\
\text { magntik }\end{array}$ & $\begin{array}{c}\text { Mineral } \\
\text { non } \\
\text { magnetik }\end{array}$ \\
\hline \multicolumn{5}{|c|}{ Penampang B-B' } \\
\hline 1 & 0.000154 & $0-0.018$ & Aluvium & $\begin{array}{c}\text { Batuan } \\
\text { sedimen }\end{array}$ \\
\hline 2 & 0.00023 & $\begin{array}{c}0.00017- \\
0.00025\end{array}$ & Lempung & $\begin{array}{c}\text { Batuan } \\
\text { sedimen }\end{array}$ \\
\hline 3 & -0.00713 & $0-0.02$ & Batu Pasir & $\begin{array}{c}\text { Batuan } \\
\text { sedimen }\end{array}$ \\
\hline 4 & -0.000032 & - & $\begin{array}{l}\text { Mineral non } \\
\text { magntik }\end{array}$ & $\begin{array}{c}\text { Mineral } \\
\text { non } \\
\text { magnetik }\end{array}$ \\
\hline \multicolumn{5}{|c|}{ Penampang C-C' } \\
\hline 1 & 0.001328 & $0-0.018$ & Aluvium & $\begin{array}{c}\text { Batuan } \\
\text { sedimen }\end{array}$ \\
\hline 2 & 0.000107 & $\begin{array}{c}0.00017 \text { - } \\
0.00025\end{array}$ & Lempung & $\begin{array}{c}\text { Batuan } \\
\text { sedimen }\end{array}$ \\
\hline 3 & -0.0011 & $0-0.02$ & Batu Pasir & $\begin{array}{c}\text { Batuan } \\
\text { sedimen }\end{array}$ \\
\hline 4 & -0.0223 & - & $\begin{array}{l}\text { Mineral non } \\
\text { magntik }\end{array}$ & $\begin{array}{c}\text { Mineral } \\
\text { non } \\
\text { magnetik }\end{array}$ \\
\hline
\end{tabular}


Untuk mengetahui struktur lapisan batuan penyusun reservoar panasbumi di Desa Lengkeka, dibutuhkan teknik pemodelan. Metode tersebut merupakan suatu metode matematika yang digunakan untuk mengolah data menjadi suatu bentuk model struktur lapisan batuan lokasi penelitian. Dalam pemodelan menggunakan pemodelan kedepan diproleh model seperti pada Gambar 7, Gambar 8 dan Gambar 9, yang menggambarkan sebaran nilai suseptibilitas dan dapat diinterpretasikan sebagai perlapisan batuan dan ditunjukan pada Tabel 3.

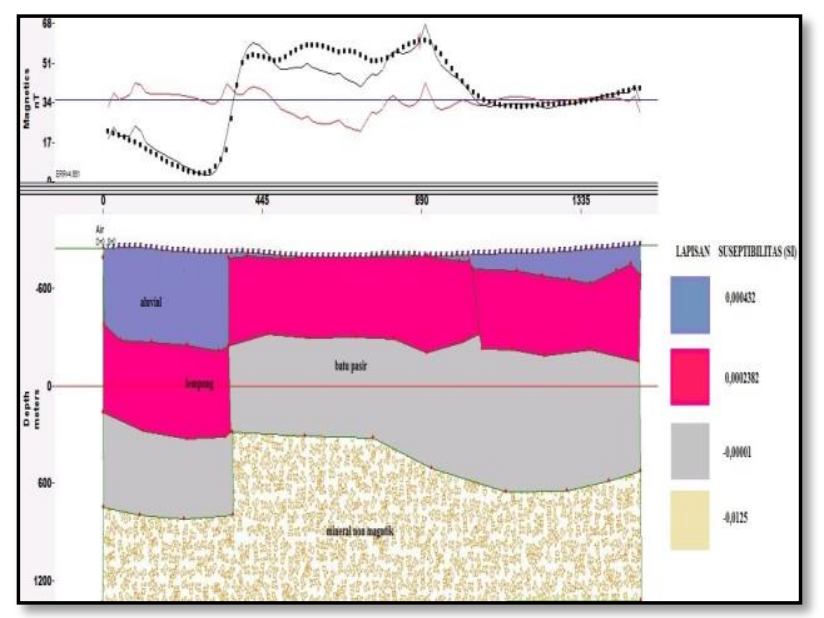

Gambar 4. Model bawah permukaan Penampang A-A'

Penampang A-A' yang ditunjukkan pada Gambar 4 bahwa model bawah permukaan tersusun atas beberapa jenis batuan dan mineral diantaranya lapisan pertama yaitu aluvium merupakan batuan termuda yang berada pada permukaan tanah dengan kedalaman 0 sampai $300 \mathrm{~m}$ dengan nilai suseptibilitas 0,000432 SI merupakan batuan sedimen. Selanjutnya lapisan kedua yaitu batuan sedimen berupa lempung dengan kedalaman 300 sampai $700 \mathrm{~m}$ dengan nilai suseptibilitas 0,002382 SI. Pada lapisan ketiga yaitu batuan sedimen berupa batu pasir dengan kedalaman 1000 sampai 1700 $\mathrm{m}$ di bawah permukaan dengan nilai suseptibilitas $-0,00001 \mathrm{SI}$.

Lapisan ketiga tersebut diduga merupakan batuan penyusun reservoir panasbumi, hal itu ditunjukkan dengan nilai suseptibilitas batuan yang bernilai minus atau batuan dengan sifat diamagnetik. Nilai suseptibilitas negatif menandakan bahwa batuan yang ada di lokasi tersebut kehilangan mineral magnetiknya sebagai akibat dari pemanasan dari sumber panas yang ada di bawah permukaan.

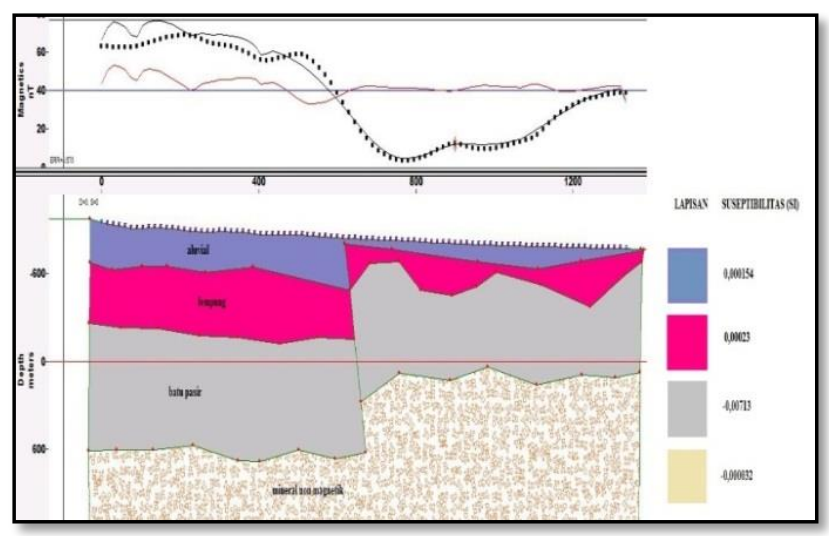

Gambar 5. Model bawah permukaan Penampang B-B'

Penampang B-B' yang ditunjukkan Gambar 5, batuan penyusun bawah permukaan lokasi penelitian berupa aluvium, dan lempung serta batu pasir yang merupakan batuan sedimen. Lapisan pertama yaitu Aluvium yang merupakan batuan termuda berada pada kedalaman 0 sampai $300 \mathrm{~m}$ dengan nilai suseptibilitas 0,000154 SI. Lapisan kedua yaitu lempung yang berada pada kedalaman 300 samapai $800 \mathrm{~m}$ dengan nilai suseptibilitas 0,00023 SI. Pada lintasan 2 batuan penyusun reservoar panasbumi yaitu batuan sedimen berupa batu pasir dengan nilai suseptibiltas -0,00713SI. Kedalaman reservoar berada pada 800 
sampai $1600 \mathrm{~m}$ di bawah permukaan. Batuan sedimen memiliki nilai suseptibilitas yang sangat kecil atau di bawah nilai 0 . Hal itu dikarenakan batuan mengalami pemanasan dari sumber panasbumi dan sebagai akibatnya batuan kehilangan sifat magnetiknya

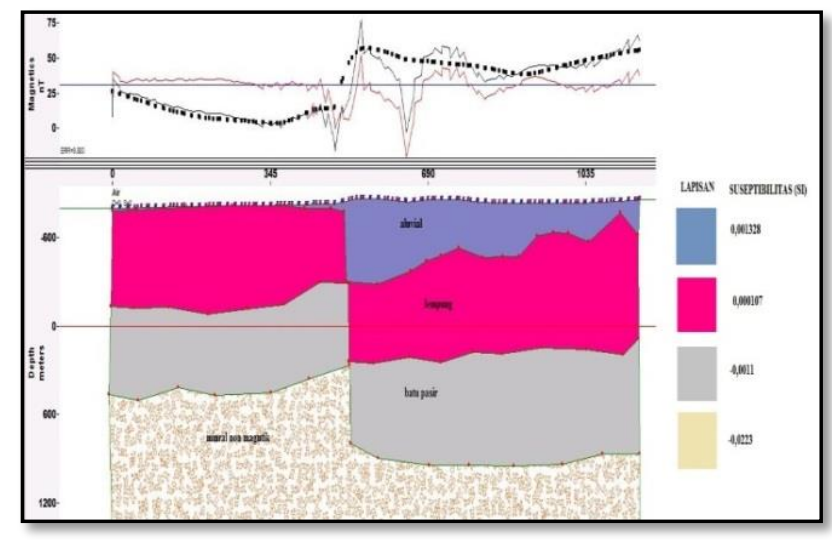

Gambar 6. Model bawah permukaan Penampang C-C'

penampang C-C' yang ditunjukkan Gambar 6, batuan penyusun bawah permukaan lokasi penelitian adalah sedimen yang berupa aluvium, dan lempung serta batu pasir. Lapisan pertama yaitu aluvium yang merupakan batuan termuda berada pada kedalaman 0 sampai $300 \mathrm{~m}$ dengan nilai suseptibilitas 0,001328 SI. Lapisan kedua yaitu lempung yang berada pada kedalaman 300 sampai $800 \mathrm{~m}$ dengan nilai suseptibilitas 0,000107 SI. Pada lintasan 3 batuan penyusun reservoar panasbumi yaitu batuan sedimen berupa batu pasir dengan nilai suseptibiltas $-0,00011$ SI. Kedalaman reservoar berada pada kedalaman 800 sampai $1600 \mathrm{~m}$ di bawah permukaan. Ketiga model penampang tersebut dengan nilai suseptibilitas yang diinterpretasikan kedalam jenis mineral dan batuan dikelompokkan kedalam tabel 3.

Berdasarkan Tabel 3 terlihat bahwa model bawah permukaan lokasi penelitian tersusun dari beberapa jenis batuan dan mineral. Dari ke 3 model yang telah diperoleh menggunakan metode geomagnet ini menggambarkan bahwa batuan penyusun bawah permukaan lokasi penelitian adalah batuan sedimen berupa Alluvial, lempung dan batu pasir.Reservoar panas bumi tersusun atas batuan sedimen berupa batu pasir dengan kedalaman $800-1600 \mathrm{~m}$ di bawah permukaan.Berdasarkan hasil yang diperoleh menggunakan metode geomagnet maka dapat diketahui reservoar panasbumi di Desa Lengkeka Kecamatan Lore Selatan Kabupaten Poso.

Hal tersebut dapat diinterpretasikan bahwa semakin kecil nilai suseptibilitas batuan semakin tinggi temperatur batuan tersebut dan diduga sebagai reservoar. Sesuai pada Tabel 3, nilai suseptibilitas yang bernilai terkecil dan negatif yaitu batuan sedimen yaitu berupa batu pasir dengan nilai suseptibilitas -0,00001 SI pada penampang A-A', $-0,00713$ SI pada penampang BB', dan $-0,0011$ SI pada penampang CC'. Batuan ini diduga sebagai reservoar atau tempat terakumulasinya fluida hydrothermal. Pada penampang model reservoar seperti yang ditunjukkan pada Gambar 5 sampai Gambar 7 tampak batuan sedimen pada kedalaman dangkal, namun diduga batuan ini adalah hasil pelapukan yang mengalami rembesan panasbumi

\section{KESIMPULAN}

Berdasarkan hasil penelitian dan pemodelan reservoar panas bumi Desa Lengkeka, Kabupaten Poso, dapat disimpulkan bahwa, Reservoar panasbumi tersusun atas batuan sedimen berupa batu pasir dengan nilai suseptibilitas Pada Penampang A-A' $-0,00001$ SI, Penampang B-B' -0,00713 SI, Penampang C-C' -0.00011 SI. Kedalaman reservoar panasbumi di Desa 8 
Lengkeka berada pada kedalam $800 \mathrm{~m} \mathrm{-}$ $1600 \mathrm{~m}$ di bawah permukaan lokasi penelitian.

\section{DAFTAR PUSTAKA}

Afandi, A., Maryanto, S., dan Rachmansyah, A., (2013), Identifikasi Reservoar Daerah Panasbumi Dengan Metode Geomagnetik Daerah Blawan Kecamatan Sempol Kabupaten Bondowoso, Jurnal Neutrino, Vol. 6, Hal 1-10.

Baligau, C.I.C., Kasim S., dan Efendi R (2017), Pemodelan Reservoir Panas Bumi Menggunakan Data Magnetik di Desa Toro Kecamatan Kulawi. Natural Science, Vol 6, Hal 159-164.

Broto, S dan Putranto T.T (2011). Aplikasi Metode Geomagnet Dalam Eksplorasi Panasbumi, Universitas Diponegro, Semarang.

Fitria, L., Yulianto, T., dan Harmoko, U., (2015), Interpretasi Struktur Bawah Permukaan Berdasarkan Data Geomagnetik Pada Daerah Mata Air Panas Jatikurung Kabupaten Semarang. Yougster Physics Journal, Vol. 4, Hal 285- 290.

Hochstein, M.P. dan Browne, P.R.L, (2000), Surface Manifestation of Geothermal System with Volcanic Heat Source, In Encyclopedia of Volcanoes, $\mathrm{H}$. Siguardson, B.F. Houghton, S.R. Mc Nutt, H. Rymer dan J. Stix (eds.), Academic Press.

Indratmoko, P., Nurwidyanto, M. I., dan Yulianto, T., (2009), Interpretasi Bawah Permukaan Daerah
Manifestasi Panasbumi Parangtritis Kabupaten Bantul DIY Dengan Metode Magnetik. Berkala Fisika, Vol. 12, Hal 153-160.

Putri, D.E., Abdullah dan Efendi R (2017), Pemodelan reservoar panasbumi menggunakan data magnetik di Desa BoraKabupaten Sigi, Gravitasi, Vol 16, Hal 1-7.

Rosanti, D.F, (2012). Korelasi antara Suseptibilitas Magnetk dengan Unsur Logam Berat pada Sekuensi Tanah di Pujon Malang. skripsi: Universitas Negeri Malang.

Saptadjil, N. M. (2009). Karakterisasi Reservoir Panasbumi. Institut Teknologi Bandung. Bandung.

Simandjuntak, Surono dan Supandjono J.B (1997). Peta Geologi Lembar Poso, Sulawesi, Skala 1: 250.000, Bakosurtanal, Bandung.

Telford, W. M., Sheriff, R. E., dan Geldart, L. P, (1996), Applied Geophysics, $2^{\text {nd }}$ Edition, Cambridge University Press, Cambridge. 